Reprod. Nutr. Dévelop., 1984, 24, (4), 469-482.

\title{
Determination of plasma non-esterified fatty acids in herbivores and man : a comparison of values obtained by manual or automatic chromatographic, titrimetric, colorimetric and enzymatic methods
}

\author{
Y. CHILLIARD $(*)$, D. BAUCHART $\left({ }^{* *}\right)$, J. BARNOUIN $\left({ }^{* *}\right)$
}

with the technical assistance of Françoise DUBOISSET $\left({ }^{*}\right)$, Jeanne FLÉCHET $\left({ }^{*}\right)$ and J. P. CHACORNAC $(* * *)$

(*) Laboratoire de la Lactation,

(**) Laboratoire d'Etude du Métabolisme énergétique,

$\left(^{* *}\right)$ Laboratoire d'Ecopathologie,

I.N.R.A., Theix, 63122 Ceyrat, France.

Summary. Non-esterified fatty acid (NEFA) contents were determined (1) in cow, goat, mare and human plasmas or sera and (2) in bovine serum albumin solutions by thin-layer and gas-liquid chromatographic methods which were compared with 6 chemical methods of determination and 2 enzymatic methods (manual and automatic). The chemical methods combined two extraction techniques (isopropanol-heptane and silicic acid-diisopropyl ether) and three determination methods (titrimetry and colorimetry using either phenol red or copper soaps). Correlations between the nine various methods were high, but in some cases regression lines were different from the bissector and species-dependent. The putative occurrence of interfering compounds or the possible effect of between-species differences in NEFA composition have been discussed. The choice of a fast method depends primarily on practical considerations, but the need to standardize each method for a given species has been stressed. Automatic enzymatic assay seemed to be suitable for routine analyses.

\section{Introduction.}

The determination of non-esterified fatty acid (NEFA) (1) concentrations is widely used in studies of lipid metabolism to estimate the intensity of body lipid mobilization (plasma NEFA) or to measure lipase activities in vitro. Many routine techniques have been developed since the publication of the Dole (1956) method.

(1) Abbreviations used : A-ENZ = automatic enzymatic ; $\mathrm{BSA}=$ bovine serum albumin ; $\mathrm{C}=$ cow $; \mathrm{CS}=$ copper soaps $; \mathrm{ES}=$ ether-silicic acid $; \mathrm{G}=$ goat $; \mathrm{GLC}=$ gas-liquid chromatography ; $\mathrm{H}=$ human; $\mathrm{HIA}=$ heptane-isopropanol-acid ; $\mathrm{M}=$ mare ; $\mathrm{M}-\mathrm{ENZ}=$ manual enzymatic ; $\mathrm{NEFA}=$ non-esterified fatty acids $; \mathrm{PR}=$ phenol red $; \mathrm{T}=$ titrimetric $; \mathrm{TLC}=$ thin-layer chromatography. 
They are generally based on the partially specific extraction of lipids by organic solvents associated with the elimination of interfering compounds such as phospholipids or volatile fatty acids (Dole and Meinertz, 1960 ; Trout, Estes and Friedberg, 1960 ; Duncombe, 1964 ; Antonis, 1965 ; Itaya and Ui, 1965 ; Laurell and Tibbling, 1967; Falholt, Lund and Falholt, 1973). After extraction, the carboxylic groups can be determined by titrimetry (Dole, 1956) or by manual (Laurell and Tibbling, 1967 ; Duncombe, 1963 ; Mosinger, 1965 ; Novak, 1965) or automatic (Antonis, 1965; Baird, Black and Faulkner, 1967) colorimetry. Recently, several enzymatic techniques have been developed that use acyl-Co-A synthetase for plasma NEFA specific assay without previous extraction (Mizuno et al., 1980 ; Okabe et al., 1980 ; Shimizu et al., 1980 ; Hosaka et al., 1981).

The reason why there are so many methods for determining NEFA is that there are a number of still unresolved difficulties in obtaining both a quantitative and a specific assay (without interfering substances). The method must be sensitive, rapid, reproducible and applicable to all animal species. Methodological studies on herbivore plasma are scarce (Crane and Lane, 1977 ; De Villiers, Van Der Walt and Procos, 1977 ; Bas, 1984) ; most have been carried out on human or rat plasma. Very few methods have been compared to a specific and quantitative reference method (Duncombe and Rising, 1973; Mc Donald-Gibson and Young, 1974 ; Brunck and Swanson, 1981), the majority (Itaya and Ui, 1965 ; Laurell and Tibbling, 1967 ; Mosinger, 1965 ; Howorth, Gibbard and Mark, 1966 ; Lorch and Gey, 1966 ; Baird, Black and Faulkner, 1967 ; Dalton and Kowalski, 1967 ; Kashket, 1971; Soloni and Sardina, 1973; Elphick, 1975; Bowyer, Cridland and King, 1978; Shimizu et al., 1980) being contrasted with the titrimetric determination of Dole and Meinertz (1960) or Trout, Estes and Friedberg (1960). Enzymatic techniques were mainly compared with the colorimetric determination of copper soaps (Mizuno et al., 1980 ; Shimizu et al., 1980 ; Hosaka et al., 1981 ; Bas, 1984) and their automation has not yet been reported.

The aim of the present work was to compare the values of the plasma or serum from three herbivores (cow, goat and mare) and man as well as of bovine serum albumin solutions, using 8 fast methods ( 6 chemical and 2 enzymatic) of NEFA determination. These methods were compared to a chromatographic technique that was both quantitative and specific. The 6 chemical methods combined 2 extractions (Trout, Estes and Friedberg, 1960 ; Antonis, 1965) and 3 assay procedures (manual titrimetry and automatic colorimetry either with phenol red or after copper soap formation). The two enzymatic methods were either a manual or an automatic adaptation of the NEFA C-test Wako. These procedures were chosen because they are widely used in research laboratories and could be either automated or used without organic solvents (enzymatic methods).

\section{Methods.}

All reagent-grade products used were purchased from E. Merck, Darmstadt, RFA unless otherwise indicated. 
Chromatographic determination (TLC and GLC). - As described by Folch, Lees and Sloane-Stanley (1957), total lipids were extracted from $10 \mathrm{ml}$ of plasma or serum in three successive extractions with $45 \mathrm{ml}$ of chloroform-methanol $2 / 1$ (V/V) after adding $0.315 \mathrm{mg}$ of pure heptadecanoic acid (internal standard). The NEFA were then separated by thin-layer chromatography on lipid-free kieselgel with hexane-diethyl ether-formic acid 40/10/1 (V/V/V) as the developing solvent (Christie, Noble and Moore, 1970). The NEFA, stained with iodine vapors and reextracted from the kieselgel with chloroform-methanol, were then methylated by boiling and refluxing the solvent for 30 min with $3 \%$ methanol- $\mathrm{HCl}$. Methyl esters were separated by isotherm gas-liquid chromatography $\left(195{ }^{\circ} \mathrm{C}\right)$ on a glass capillary column $(40 \mathrm{~m} \times 0.15 \mathrm{~mm}$ i.d.) coated with FFAP (Sulpelco Inc., Bellefonte) and detected by flame ionization (Packard type 427). The weight percentage was calculated by electronic integration (DELSI, ICAP 5 model, 92150 Suresnes, France).

The samples were analysed in triplicate, the first one without adding any internal standard and the other two with an internal standard. Otherwise, the concentration and composition of contaminant fatty acids (blank) appearing during sample preparation in spite of many preventive measures, such as solvent distillation, kieselgel and filter delipidation, sulfochromic treatment of glassware, were determined by the purity of internal standards extracted and methylated alone in the same conditions as the samples. The molar concentration of every fatty acid of the NEFA fraction was calculated by referring to the quantity of internal standard after subtracting the endogenous heptadecanoic acid and the interfering contaminant fatty acids.

\section{Fast extraction.}

HIA method (heptane-isopropanol-sulfuric acid). - NEFA from $1 \mathrm{ml}$ of plasma or serum were extracted with $5 \mathrm{ml}$ of heptane-isopropanol-1 $\mathrm{N}$ sulfuric acid 10/40/1 (V/V/V). After adding heptane and water, decarbonated nitrogen saturated with heptane was bubbled $(10 \mathrm{sec})$ into the solution. The upper layer was removed and washed with $0.05 \%$ aqueous $\mathrm{H}_{2} \mathrm{SO}_{4}$ to eliminate interfering acid substances (Trout, Estes and Friedberg, 1960). As opposed to the findings of Bowyer, Cridland and King (1978), no differences were noted between acid water and distillate water washings $(226 \pm 88 \mu \mathrm{M}$ vs $234 \pm 96 \mu \mathrm{M}$ for 25 plasma samples ; difference between paired values : $8 \pm 24 \mu \mathrm{M})$. Therefore, the type of washing proposed by Trout, Estes and Friedberg (1960) was used.

ES method (di-isopropylic ether-silicic acid). - NEFA from $1 \mathrm{ml}$ of plasma or serum were extracted with $20 \mathrm{ml}$ of di-isopropylic ether in the presence of silicic acid $(3 \mathrm{~g})$, which eliminated the phospholipids from the extract (Antonis, 1965). After removing the solvent by evaporation, the NEFA were dissolved in a solvent corresponding to the determination method to be used.

Both the HIA and ES extraction procedures were used in combination with each of the three fast methods of NEFA determination described below, giving six chemical determinations in all. In each case, the blank value (water instead of plasma) was substracted from measured values, and standardization was carried out with palmitic acid solutions treated in the same manner as the samples. 


\section{Chemical determination}

Titrimetric method $(T$.$) . - The acidity of fatty acid solutions in heptane was$ titrated with $0.01 \mathrm{~N} \mathrm{NaOH}$ in isopropanol. Titration was carried out with a $0.5-\mathrm{ml}$ capacity microburet (Metrohm, model E 457). The indicator solution was $0.1 \%$ thymol blue in isopropanol.

Phenol red method (PR). - A Technicon autoanalyser was used as described by Baird, Black and Faulkner (1967). Fatty acid solutions in heptane were mixed under $\mathrm{CO}_{2}$-free air with the colored reagent (phenol red and sodium barBital dissolved in ethanol and heptane). Extinction, resulting from the conversion of alkaline phenol red into its yellow acid form, was measured at $560 \mathrm{~nm}$.

Copper soap method (CS). - A Technicon autoanalyser was used as described by Antonis (1965). The chloroform solution of fatty acids reacted with the copper reagent to form copper soaps that subsequently formed complexes with zinc dibenzyldithiocarbamate $10.2 \%$ in chloroform ; Brumby et al., 1975) instead of with sodium diethyldithiocarbamate in butanol (Bas, Rouzeau and Morand-Fehr, 1980). Extinction was measured at $440 \mathrm{~nm}$.

Enzyme assay using manual (M-ENZ) or automatic (A-ENZ) method.

Plasma or serum samples were directly analysed (NEFA C-test Wako; Biolyon, ref. 46551) either manually (M-ENZ) or automatically (A-ENZ) on an Isamat single-channel discrete analyser (ISA Biologie, 94230 Cachan, France). The NEFA were activated by acyl-CoA synthetase and then oxidized by acyl-CoA oxidase with the simultaneous production of $\mathrm{H}_{2} \mathrm{O}_{2}$ which was reduced by peroxidase to yield a chromogen measured at $550 \mathrm{~nm}$.

With the A-ENZ procedure, the contents of one flask of " reagent $A \|\left({ }^{2}\right)$ were dissolved with $7 \mathrm{ml}$ of "buffer $A$ " ${ }^{(2)}$ ( (" solution $A$ »). "Solution $B$ " was prepared by dissolving the contents of one flask of « reagent $B$ » $\left(^{2}\right)$ with $14 \mathrm{ml}$ of " buffer $B$ » $\left({ }^{2}\right)$. Twelve microliters of plasma or serum were sampled and mixed with $120 \mu$ of solution $A$ at $37{ }^{\circ} \mathrm{C}$ then incubated for $130 \mathrm{sec}$ (two revolutions of the plate). Thereafter, $240 \mu \mathrm{l}$ of solution B were added and the initial optical density was read $12 \mathrm{sec}$ later. The reaction then continued for $130 \mathrm{sec}$ before final optical density was recorded. NEFA concentrations were calculated automatically from the increase in optical density (final o.d.-initial o.d.) in samples and in oleic acid standards composed of dilutions of the oleic acid kit standard. The reduction in the incubation and reaction times from $10 \mathrm{~min}$ to $130 \mathrm{sec}$ did not alter the results significantly.

With the M-ENZ method, $50 \mu \mathrm{l}$ of plasma or serum were analysed, as indicated in the kit instructions. Each sample blank value was subtracted from the sample value.

(2) Reagent $A$ (content per flask) : acyl-CoA synthetase (3 U); ATP (50 $\mu$ mol); ascorbate oxidase (15 U) : amino-4 antipyrine (15 $\mu \mathrm{mol})$; $\operatorname{CoA}(7 \mathrm{mg})$. - Buffer $A$ : phosphate buffer, $\mathrm{pH} 6.9$ $(50 \mathrm{mM}) ; \mathrm{Mg} \mathrm{Cl}_{2}(3 \mathrm{mM})$; Triton X-100 (0.2\%). - Reagent $B$ (content per flask) : acyl-Co A oxidase (132 U) ; peroxidase (150 U) ; 3-methyl- $N$ ethyl-N (6 hydroxyethyl) aniline $(20 \mu$ mol). - Buffer $B$ : Triton $\mathrm{X}-100(0.1 \%)$. (These indications are given in the kit instructions). 
Assays

Experiment 1. - The nine methods or variants described above were used to determine the NEFA content in the 14 samples on table 1. Each sample was analysed on 4 separate days, except in the case of the TLC-GLC and M-ENZ methods which were analysed on 2 separate days. The total number of assays is shown in annex 1.

\section{TABLE 1}

Samples in experiment 1.

\section{Cow Plasma (•) (a) :}

$\mathrm{C}_{1}$ - Pooled post-prandial plasma from 3 dry cows.

$\mathrm{C}_{2}$ - Pooled pre-prandial plasma from 5 cows 4-6 weeks post-partum.

$\mathrm{C}_{3}$ - Pooled pre-prandial plasma from 3 cows 1 week post-partum.

$\mathrm{C}_{4}$ - Pooled plasma from 2 dry cows after a $48 \mathrm{~h}$ fast.

Bovine serum albumin (BSA, $\mathbf{A}$ ):

$B_{1}$ - BSA from Sigma Chemical Company (fraction V, Art. A-4503, Lot 120 F-0641), $5 \%$ (W/V) in $0.154 \mathrm{M} \mathrm{NaCl}$.

$B_{2}$ - BSA from Sigma, $10 \%$.

$B_{3}$ - BSA from Armour Pharmaceutical Company (Fraction V, Art. 2293, Lot M 4709), $10 \%$.

$\mathrm{B}_{4}$ - BSA from Armour, $12 \%$.

Mare plasma (ם) :

$M_{1}$ - Pooled post-prandial plasma from 5 dry mares.

$M_{2}$ - Plasma from 1 mare, 6 weeks post-partum and after a $48 \mathrm{~h}$ fast.

Goat plasma $(\boldsymbol{\nabla})$ :

$\mathrm{G}_{1}$ - Pooled plasma from 3 dry goats after a $24 \mathrm{~h}$ fast.

$\mathrm{G}_{2}$ - Pooled plasma from 3 dry goats after a $65 \mathrm{~h}$ fast.

Human $\operatorname{serum}(\triangle)$ :

$H_{1}$ - Lyophilised human control serum (Precilip (B)) from Boehringer-Manheim (Art. 125067 ; Lot 4-372) reconstituted using $7 \mathrm{ml}$ of water per bottle.

$\mathrm{H}_{2}$ - Lyophilised control serum (human serum + egg yolk) (Precilip ${ }^{\circledR}$ E.L.) from BoehringerManheim (Art. 225061; Lot 3-305) reconstituted using $6 \mathrm{ml}$ of water per bottle.

(a) Plasma from heparinized blood $(5 \mathrm{U} / \mathrm{ml})$, albumin solutions and reconstituted sera were stored $\left(-20^{\circ} \mathrm{C}\right)$ in different tubes and thawed just before each determination.

Experiment 2. - The NEFA content of 253 heparinized $(5 \mathrm{U} / \mathrm{ml})$ cow plasma samples was determined in duplicate with the HIA-T method and once with the A-ENZ method. Twenty-one Holstein-Friesian cows receiving different diets were used ; their blood was sampled at different hours of the day and at various stages during the last 2 months before and the first 5 months after parturition. The plasma was stored in separate tubes at $-20^{\circ} \mathrm{C}$ and thawed just before the different assays.

Experiment 3. - Ten samples of heparinized $(30 \mathrm{U} / \mathrm{ml})$ human plasma and 5 human serum samples from a medical analysis laboratory were used. In order to increase the dispersion of NEFA contents, an aliquot of each sample was 
immediately frozen and another was left to stand for $48 \mathrm{~h}$ before freezing. The resulting 30 samples were analysed by the HIA-T and A-ENZ procedures.

\section{Results.}

\section{Reproducibility of the different methods.}

The mean values of the NEFA contents in the 14 samples of experiment 1 are shown on figures 1 and 2 . Intra-sample coefficients of variation were 6-8\% with the TLC-GLC, HIA and M-ENZ methods ; $9-10 \%$ with the ES method and $12 \%$ with the A-ENZ method (annex 1). A value of $3.1 \%$ was obtained with the HIA-T procedure in experiment 2. In other separate experiments (unpublished results), the reproducibility of the A-ENZ method was between 3 and $13 \%$ due to the NEFA content of the studied samples (SD $=30-75 \mu \mathrm{M})$.

\section{Relationships between methods.}

Experiment 1. - In comparison with the reference chromatographic procedure, higher values were noted in human serum samples with the ES extraction $(+22$ to $+55 \%)$; to a lesser extent, this was also true for the HIA extraction $(+10$ to $+29 \%)$ (fig. 1). Residues $(Y-\bar{y})$ were more than twice the regression
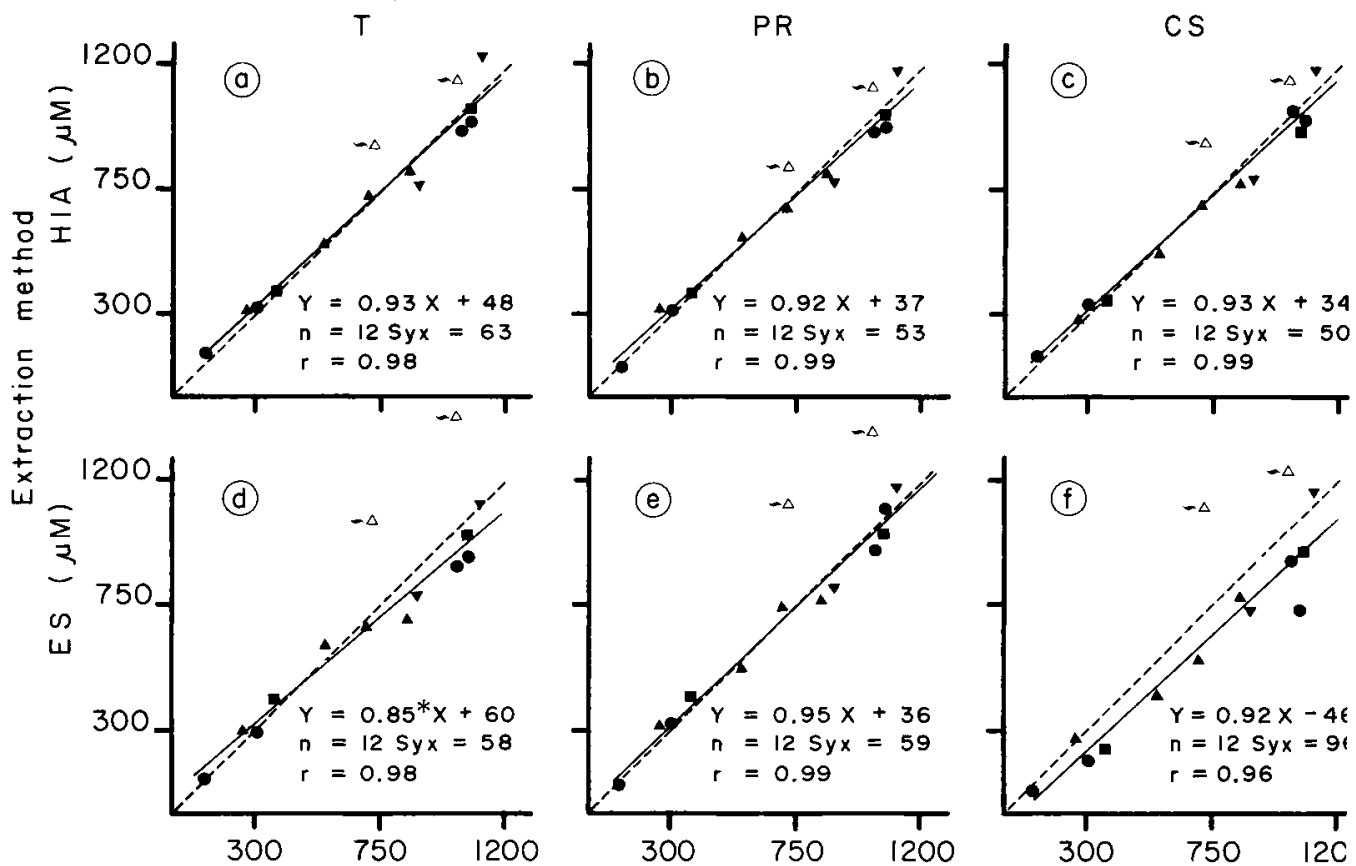

Reference method, TLC - GLC $(X)(\mu M)$

FIG. 1. - Ccmparison of two extraction and three determination methods (Y) with the TLC-GLC reference method $(\mathrm{X})$ (Experiment 1).

Extraction methods : HIA in $a, b, c$ and ES in d, e, f. Methods for determining extracted NEFA : T $(a, d), P R(b, e)$ and CS (c, f). Symbols as in table 1.

$\sim$ Sample not included in the regression line; * = slope significantly different from $1(\mathrm{P}<0.05)$. 


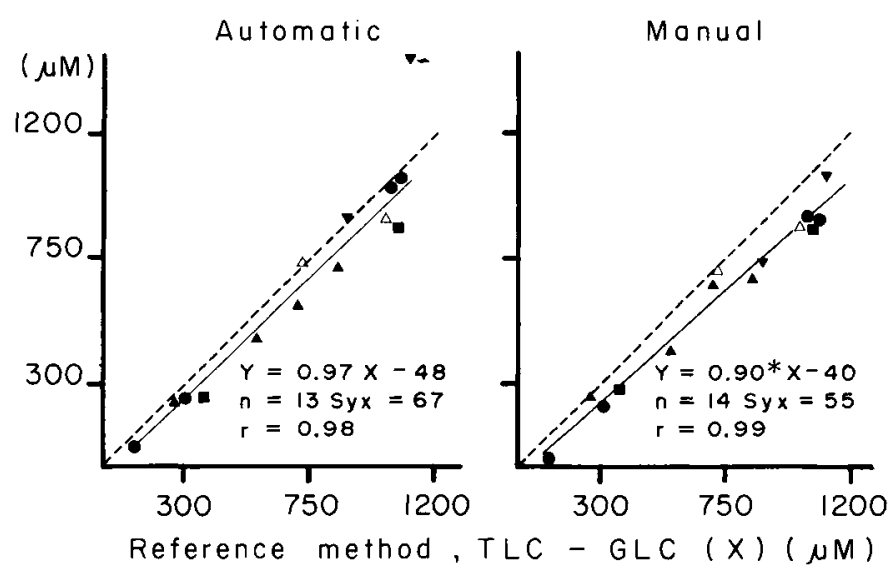

FIG. 2. - Comparison of automatic and manual enzymatic determination of NEFA (Y) Legend as in figure 1. with the TLC-GLC reference method (X) (Experiment 1).

standard deviation (Syx) for these samples, and thus were not included in the regression equations which were calculated only for herbivores ( $n=12$; fig. 1 ). On the other hand, results obtained with enzymatic procedures for human sera did not diverge from the general relationship observed for the other 3 species (fig. 2). For unknown reasons, one goat plasma sample (G2) systematically (22 repetitions) gave higher values with the A-ENZ method than with the TLCGLC method or the M-ENZ (fig. 2) and chemical methods (fig. 1). Thus, the regression equation was calculated with only 13 samples for the A-ENZ procedure.

With these restrictions, the results obtained with the various fast techniques were highly correlated with those of the TLC-GCL method (figs. 1, 2) and residual standard deviations were quite low $(50-100 \mu \mathrm{M}$, i.e. about $10 \%$ of the mean values). Furthermore, NEFA contents were similar since regression lines were near the bissectors. Indeed, the intercepts were never significantly different from zero, and the slopes differed from 1 ( $P<0.05$ ) only with the ES-T (fig. 1) and M-ENZ (fig. 2) methods.

Experiment 2. - NEFA contents as determined by HIA-T and A-ENZ procedures in 253 bovine plasma samples were highly correlated (table 2). However, the A-ENZ method gave lower values for low NEFA contents $(<200 \mu \mathrm{M})$ and higher values for high NEFA contents. Regression equations between these two methods were comparable in experiments 1 and 2 (table 2).

Experiment 3. - With human plasma or serum, the A-ENZ procedure gave slightly but significantly lower results than the HIA-T on the full range of contents (fig. 3). Samples left standing for $48 \mathrm{~h}$ at room temperature before freezing showed much higher values than the same samples that were immediately frozen $(+80.7 \pm 43.7 \%$ for the 15 pairs $)$. On the other hand, values obtained on human sera in experiment 1 were close to the regression line in experiment 3 


\section{TABLE 2}

HIA-T and A-ENZ method values with 253 bovine plasma samples (Experiment 2).

\begin{tabular}{|c|c|c|}
\hline & $\begin{array}{l}\text { HIA-T Method } \\
\qquad(X)\end{array}$ & $\begin{array}{l}\text { A-ENZ method } \\
(Y)\end{array}$ \\
\hline 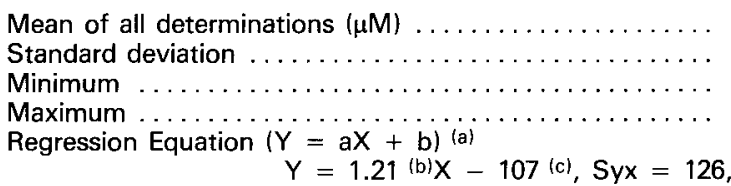 & $\begin{array}{r}541 \\
498 \\
85 \\
2883 \\
=0.98, \mathrm{n}=253\end{array}$ & $\begin{array}{r}546 \\
615 \\
10 \\
3270\end{array}$ \\
\hline
\end{tabular}

(a) The corresponding equation calculated on 11 samples (without human sera and $G_{2}$ sample) in Experiment 1 was :

$$
Y=1.09 X-120, \text { Syx }=97, r=0.96 .
$$

(b) Slope significantly different from $1(\mathrm{P}<0.01)$.

(c) Intercept significantly different from $0(P<0.01)$.

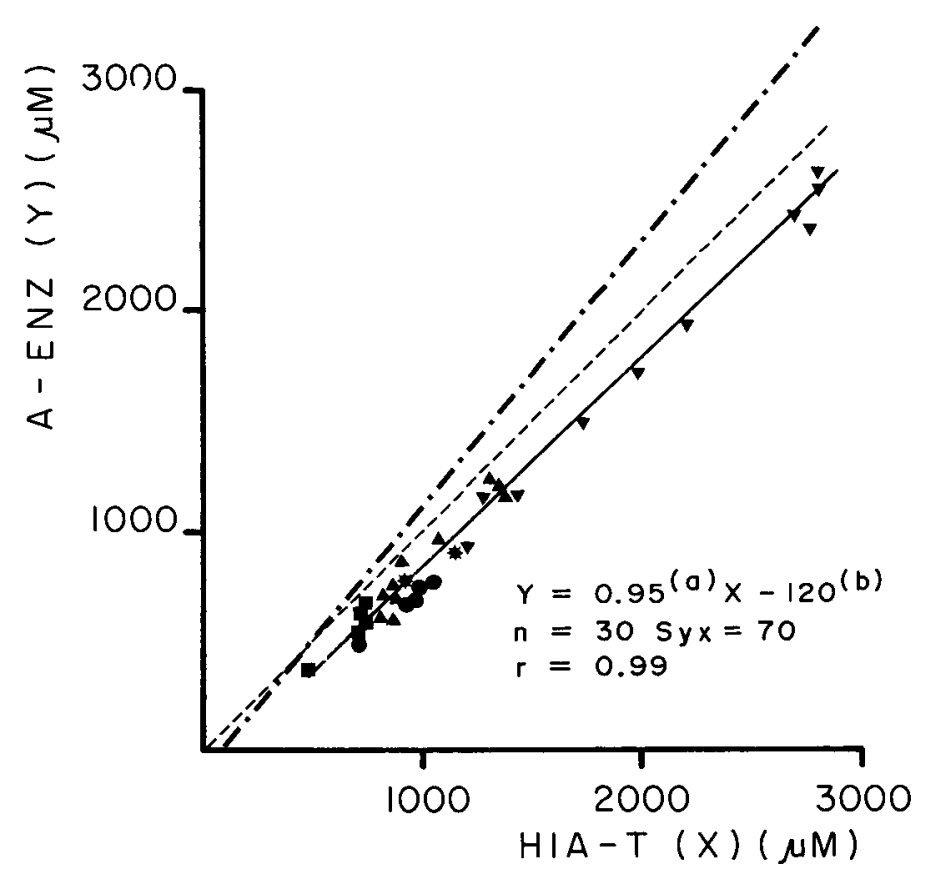

FIG. 3. - Comparison of HIA-T and A-ENZ methods with human sera and plasma (Experiment 3).

\section{Sera}

Plasmas

Frozen immediately :

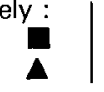

\section{Stood at room temperature for $48 \mathrm{~h}$ before freezing :}

* Human sera from experiment 1 (not included in the regression line) line from experiment 2 on 253 cow plasma samples (see table 2) ; - - = Bissector.

(a) Slope significantly different from $1(\mathrm{P}<0.05)$.

(b) Intercept significantly different from $0(P<0.01)$. 
(fig. 3), whereas the regression lines for bovine plasma and for human sera and plasma were quite different (experiment 2 vs experiment 3 ; fig. 3 ). The presence or absence of heparin in the samples did not modify the ratio between the A-ENZ and HIAT methods, in accordance with data from experiment 1 (fig. 2).

\section{Discussion.}

The reproducibility of the different methods, determined by standard deviations and coefficients of variation, was similar to or lower than that noted in other studies (Trout, Estes and Friedberg, 1960; Elphick, 1975; Chilliard, Dorleans and Fehr, 1977 ; Crane and Lane, 1977; Rogiers, 1977; Bowyer, Cridland and King, 1978 ; Höckel et al., 1980 ; Okabe et al., 1980 ; Shimizu et al., 1980 ; Bas, Rouzeau and Morand-Fehr, 1980 ; Bas, 1984).

Chemical methods of extraction and determination. - Several authors have claimed that the ES extraction technique did not fully extract albumin-bound NEFA (Lorch and Gey, 1966 ; Baird, Black and Faulkner, 1967 ; Falholt, Lund and Falholt, 1973 ; Bowyer, Cridland and King, 1978), but these results (fig. 1) did not allow any similar conclusion in the range of studied concentrations. Otherwise, this method overestimated the NEFA values of human plasma in experiment 1. Further investigations are needed to determine the possible interferences between this kind of sample and method. The higher content of polyunsaturated fatty acids in human NEFA was not implicated because mare plasma, also rich in polyunsaturated fatty acids (annex 2), was not overestimated using the same method ( 3 ). The HIA extraction procedure with washing recommended by Trout, Estes and Friedberg (1960), gave very similar values to those of the reference chromatography (fig. 1) and did not lead to interferences with other compounds, except possibly with human sera or human plasma (figs. 1, 3).

The titrimetric (T) and colorimetric (PR and CS) methods gave very similar results (fig. 1) in agreement with previous studies (Mosinger, 1965; Lorch and Gey, 1966 ; Baird, Black and Faulkner, 1967 ; Kashket, 1971 ; Elphick, 1975 ; Crane and Lane, 1977 ; Bowyer, Cridland and King, 1978). However, the Antonis method (1965) gave lower values $(\simeq 10 \%)$ than the reference procedure. This underestimate could not be attributed to the ES extraction step any more than to the CS colorimetric step (Fig. 1).

Manual or automatic enzyme assay method. - NEFA concentrations determined by the manual enzymatic method gave lower values $(10 \%)$ than the reference method (fig. 2). This might be due to fatty acids with more than 18 carbon atoms since they accounted for 4 to $11 \%$ in the different samples (annex 2) and could not have been activated by the acyl-Co A synthetase of $P$. aeruginosa (Shimizu et al., 1980). Comparisons of different manual methods of enzymatic assay $(Y)$ with several colorimetric methods $(X)$ using human or goat plasma or sera gave regression lines with slope values between 0.9 and 1.2

(3) The fact that bovine and caprine NEFA plasmas were poor in polyunsaturated fatty acids (annex 2) was the result of fatty acid biohydrogenation of the feed by rumen microflora (Kepler et al., 1966). 
(Mizuno et al., 1980 ; Okabe et al., 1980 ; Shimizu et al., 1979, 1980 ; Hosaka et al., 1981 ; Bas, 1984). In experiment 3, the NEFA values of human samples were lower with the automatic enzymatic method than with the procedure of Trout, Estes and Friedberg (1960), even using samples with very high NEFA content (fig. 3). The difference with the results of experiment 2 using cow plasma could be explained either by the putative interference of compounds in human sera with the HIA-T method (fig. 1) or by the different NEFA compositions of these two species (man has a lower stearic acid and a higher polyunsaturated fatty acid content - annex 2).

In other respects, the increasing NEFA concentrations at room temperature confirmed the results of other authors (Fairweather and Layton, 1967; Rogiers, 1978; Giacomini et al., 1980). Contrary to indications in the kit instructions, heparin did not affect ENZ method results (figs. 2, 3 and unpublished results). In the study of Matsubara et al. (1983), high concentrations of heparin $(30 \mathrm{U} / \mathrm{ml})$ caused only a $50 \mu \mathrm{M}$ decrease in the recorded values.

The present study shows that the enzymatic method can be automated to allow very high assay frequency (80-100 samples/h/operator). However, in the conditions of this experiment, the automatic method was less reproducible than the manual method, possibly owing to a smaller sample size. Nevertheless, this method was highly correlated with and close to both the reference procedure (fig. 2) and the Trout method (table 2, fig. 3).

Contrary to the conclusions of Duncombe and Rising (1973), the various fast methods of NEFA assay test were suitable for quantitative and specific measurements in herbivore plasma (cow, mare, goat). However, these techniques must be standardized using regression equations calculated, when possible, for each species studied.

\section{Conclusion.}

The choice of one of the determination methods depends on its cost, rapidity, apparatus availability and the use of organic solvents ; the ES extraction procedure is time-consuming, expensive, liable to interfere with human plasma and, therefore, not worth being retained. The techniques using Dole extraction (1956) and the washing proposed by Trout, Estes and Friedberg (1960) are accurate, fast and relatively inexpensive. The enzymatic method is fast, specific and does not use organic solvents. It is more expensive in reagents but may be automated and adapted to very small samples after being strictly standardized for the different operating conditions and the animal species involved.

Reçu en janvier 1984. Accepté en mars 1984.

Acknowledgements. - The authors wish to thank Mr. M. Doreau for helping with the statistical analysis and for providing the mare plasmas, $\mathrm{Mr}$. $\mathrm{Cl}$. Champredon for providing the goat plasmas and Mr. P.-J. Bargnoux (laboratoire de Biochimie, Centre Jean Perrin, F-63000 Clermont-Ferrand) for providing the human plasmas and sera. 
Résumé. Mesure des acides gras non estérifiés plasmatiques chez les herbivores et l'homme; comparaison des résultats obtenus par des méthodes chromatographiques, titrimétriques, colorimétriques et enzymatiques, manuelles ou automatisées.

Les teneurs en acides gras non estérifiés ont été mesurées dans le plasma ou le sérum de vache, de chèvre, de jument et humain, et dans des solutions de sérum albumine bovine, par chromatographie sur couche mince puis gaz-liquide, ainsi que par six méthodes chimiques et deux méthodes enzymatiques (manuelle et automatique). Les méthodes chimiques sont les combinaisons de deux méthodes d'extraction (isopropanol-heptane et acide silicique-éther di-isopropylique) et de trois méthodes de dosage (titrimétrie et colorimétrie utilisant le rouge de phénol ou les savons de cuivre). Les corrélations entre les 9 méthodes sont élevées, mais il faut souligner que les droites de régression entre méthodes sont parfois différentes de la bissectrice et qu'il existe des effets liés à l'espèce. La présence éventuelle de substances interférentes, ou l'influence possible des différences de composition en acides gras des AGNE selon les espèces sont discutées. En définitive, le choix d'une méthode de dosage rapide dépend essentiellement de considérations pratiques à condition que cette méthode soit correctement étalonnée pour l'espèce étudiée. Le dosage enzymatique automatique semble être une méthode de choix pour des analyses de routine.

\section{ANNEX 1}

Reproducibility of the different methods.

\begin{tabular}{|c|c|c|c|c|c|c|}
\hline $\begin{array}{l}\text { Extraction } \\
\text { method }\end{array}$ & $\begin{array}{c}\text { Sample } \\
\text { size } \\
(\mathrm{ml})\end{array}$ & $\begin{array}{l}\text { Determination } \\
\text { method }\end{array}$ & $\begin{array}{c}\text { Overall } \\
\text { mean } \pm S . D \text {. } \\
(\mu \mathrm{M} ; \mathrm{n}=14)\end{array}$ & $\begin{array}{l}\text { Number } \\
\text { of assays } \\
\text { (a) }\end{array}$ & $\begin{array}{l}\text { Pooled } \\
\text { intra-sample } \\
\text { standard } \\
\text { deviation } \\
\text { ( } \mu \mathrm{M}) \\
\text { (b) }\end{array}$ & $\begin{array}{c}\text { Pooled } \\
\text { intra-sample } \\
\text { coefficient } \\
\text { of variation } \\
(\%) \\
\text { (b) }\end{array}$ \\
\hline
\end{tabular}

\begin{tabular}{ccccccc} 
(c) & & & & & \\
CM & 10 & TLC-GLC & $718( \pm 344)$ & 28 & 41.4 & 5.8 \\
\hline \multirow{3}{*}{ HIA } & 1 & T & $739( \pm 340)$ & 237 & $41.3^{(\mathrm{d})}$ & \multicolumn{1}{c}{5.8 (d) } \\
& 1 & PR & $721( \pm 335)$ & 153 & 45.3 & 6.6 \\
& 1 & CS & $730( \pm 342)$ & 182 & 53.8 & 7.0 \\
\hline \multirow{2}{*}{ ES } & 1 & T & $735( \pm 368)$ & 113 & 71.6 & 10.1 \\
& 1 & PR & $771( \pm 381)$ & 86 & 70.6 & 9.2 \\
& 1 & CS & $675( \pm 384)$ & 171 & 60.2 & 9.5 \\
\hline- & 0.05 & M-ENZ & $606( \pm 314)$ & 36 & 47.6 & 7.7 \\
- & 0.012 & A-ENZ & $678( \pm 393)$ & 404 & 73.1 & 11.7 \\
\hline
\end{tabular}

(a) Total number of assays on 14 samples (Experiment 1) on separate days (see text).

(b) The pooled intra-sample standard deviation and coefficient of variation (CV) were calculated from standard deviations (SDi), mean values $(\overline{\mathrm{X}} \mathrm{i})$ and number of repetitions (ni) per sample (i), using the formulae :

$$
\begin{aligned}
& \text { "Pooled SD» }=\left\{\sum_{i=1}^{1+}\left(n_{i}-1\right)\left(S D_{i}\right)^{2} / \sum_{i=1}^{14}\left(n_{i}-1\right)\right\}^{1,2} \\
& \text { and «Pooled CV » = " Pooled SD»/( } \left.\sum_{i=1}^{14} n_{i} \bar{X}_{i} / \sum_{i=1}^{14} n_{i}\right)
\end{aligned}
$$

(c) $\mathrm{CM}=$ Chloroform-Methanol

(d) Standard deviation calculated in Experiment 2 from 253 duplicate $\left\langle x_{1}, x_{2}\right)$ analyses (HIA-T method) of bovine plasma, using the formula :

$\mathrm{SD}=\left\{\Sigma\left(\mathrm{x}_{1}-\mathrm{x}_{2}\right)^{2 / 2} \mathrm{n}\right\}^{1 / 2}$, was $16.8 \mu \mathrm{M}$ (coefficient of variation of duplicates $=3.1 \%$ ). 
ANNEX 2

NEFA composition (molar \%) of the different samples described on table 1.

\begin{tabular}{|c|c|c|c|c|c|c|}
\hline \multicolumn{7}{|c|}{ Origin } \\
\hline $\begin{array}{l}\text { Fatty } \\
\text { acids }\end{array}$ & $\begin{array}{l}\text { Goat } \\
(n=2)\end{array}$ & $\begin{array}{c}\text { Cow } \\
\{n=4\}\end{array}$ & $\begin{array}{c}\text { BSA } \\
(n=4\rangle\end{array}$ & $\begin{array}{c}\text { Mare } \\
\{n=2\}\end{array}$ & $\begin{array}{l}\text { Human } \\
\left(\mathrm{H}_{1}\right)\end{array}$ & $\begin{array}{l}\text { Precilip } \\
\text { EL }\left(\mathrm{H}_{2}\right)\end{array}$ \\
\hline$\leq \mathrm{C}_{12: 0} \ldots \ldots \ldots$ & 7.6 & 3.6 & 3.8 & 5.1 & 3.7 & 6.9 \\
\hline$C_{14: 0}+C_{14: 1} \ldots \ldots$ & 4.2 & 6.6 & 7.0 & 5.2 & 3.7 & 5.3 \\
\hline $\mathrm{C}_{16: 0} \ldots \ldots \ldots \ldots$ & 14.9 & 22.8 & 22.4 & 24.3 & 44.4 & 24.2 \\
\hline$C_{16: 1} \ldots \ldots \ldots \ldots$ & 0.4 & 2.4 & 4.2 & 6.4 & 3.1 & 4.2 \\
\hline $\mathrm{C}_{18: 0} \ldots \ldots \ldots \ldots$ & 31.3 & 25.0 & 19.0 & 10.1 & 8.3 & 10.6 \\
\hline $\mathrm{C}_{18: 1} \ldots \ldots \ldots \ldots$ & 20.6 & 24.2 & 23.6 & 24.4 & 15.0 & 18.7 \\
\hline $\mathrm{C}_{18: 2} \ldots \ldots \ldots \ldots$ & 1.7 & 3.0 & 6.9 & 4.7 & 9.1 & 13.6 \\
\hline $\mathrm{C}_{18: 3} \ldots \ldots \ldots \ldots$ & 1.4 & 0.4 & 0.2 & 11.2 & 0.2 & 0.7 \\
\hline $\begin{array}{l}\text { odd }+ \text { branched chain } \\
\text { fatty acids } \ldots . . .\end{array}$ & 5.8 & 7.5 & 7.2 & 4.6 & 1.1 & 7.6 \\
\hline $\mathrm{C}_{20: 0}+\mathrm{C}_{22: 0} \ldots \ldots$ & 1.3 & 0.5 & 0.4 & - & 0.6 & 0.5 \\
\hline monouns. $\geq \mathrm{C}_{20} \quad \ldots$ & 3.2 & - & 1.3 & - & 1.4 & 0.4 \\
\hline polyuns. $\geq C_{20} \ldots$ & 5.0 & 3.9 & 3.7 & 3.7 & 9.0 & 6.5 \\
\hline Other fatty acids .... & 2.6 & 0.1 & 0.3 & 0.3 & 0.4 & 0.8 \\
\hline
\end{tabular}

\section{References}

ANTONIS A., 1965. Semiautomated method for the colorimetric determination of plasma free fatty acids. J. Lipid Res., 6, 307-312.

BAIRD J. D., BLACK M. W., FAULKNER D. E., 1967. Semi-automated method for the determination of free fatty acids in plasma. $J$. clin. Path., 20, 905-909.

BAS P., 1984. Détermination enzymatique des acides gras non estérifiés dans le plasma de chèvre. Ann. Rech. vét., 15 (1), sous presse.

BAS P., ROUZEAU A., MORAND-FEHR P., 1980. Variations diurnes et d'un jour à l'autre de la concentration de plusieurs métabolites sanguins chez la chèvre en lactation. Ann. Rech. vét., 11, 409-420.

BOWYER D. E., CRIDLAND J. S., KING J. P., 1978. A novel, semi-automated method for the estimation of free fatty acid in serum or plasma. J. Lipid Res., 19, 274-280.

BRUMBY P. E., ANDERSON M., TUCKLEY B., STORRY J. E., HIBBITT K. G., 1975. Lipid metabolism in the cow during starvation-induced ketosis. Biochem. J., 146, 609-615.

BRUNK S. D., SWANSON J. R., 1981. Colorimetric method for free fatty acids in serum validated by comparison with gas chromatography. Clin. Chem., 27, 924-926.

CHILLIARD Y., DORLEANS M., FEHR P. M., 1977. Mise en évidence d'une activité lipoprotéinelipasique dans le tissu adipeux de chèvre : comparaison de trois méthodes d'extraction. Ann. Biol. anim. Bioch. Biophys., 17, 107-112.

CHRISTIE W. W., NOBLE R. C., MOORE J. H., 1970. Determination of lipid classes by a gaschromatographic procedure. Analyst, 95, 940-944. 
CRANE B., LANE C., 1977. Modified semi-automated method for free acids in serum. J. clin. Pathol., 30. 754-757.

DALTON C., KOWALSKI C., 1967. Automated colorimetric determination of free fatty acids in biologic fluids. Clin. Chem., 13, 744-751.

DE VILLIERS S., VAN DER WALT J. G., PROCOS J., 1977. An accurate, sensitive and reproducible method for the colorimetric estimation of free fatty acids in plasma. Onderstepoort J. Vet. Res., 44, 169-172.

DOLE V. P., 1956. A relation between non-esterified fatty acids in plasma and the metabolism of glucose. J. chin. Invest., 35, 150-154.

DOLE V. P., MEINERTZ H., 1960. Microdetermination of long-chain fatty acids in plasma and tissues. J. biol. Chem., 235, 2595-2599.

DUNCOMBE W. G., 1963. The colorimetric micro-determination of long-chain fatty acids. Biochem. J., 88, 7-10.

DUNCOMBE W. G., 1964. The colorimetric micro-determination of non-esterified fatty acids in plasma. Clin. chim. Acta, 9, 122-125.

DUNCOMBE W. G., RISING T. H., 1973. Quantitative extraction and determination of nonesterified fatty acids in plasma. J. Lipid Res., 14, 258-261.

ELPHICK M. C., 1975. Automated modification of Duncombe's method for the ultramicro determination of serum free fatty acids. J. Lipid Res., 19, 274-280.

FAIRWEATHER D. V. I., LAYTON R., 1967. Observations on the collection and handling of blood samples for N.E.F.A. estimation. J. clin. Path., 20, 665-667.

FALHOLT K., LUND B., FALHOLT W., 1973. An easy colorimetric method for routine determination of free fatty acids in plasma. Clin. chim. Acta, 46, 105-111.

FOLCH J., LEES M., SLOANE STANLEY G. H., 1957. A simple method for the isolation and purification of total lipids from animal tissues. J. biol. Chem., 226, 497-509.

GIACOMINI K. M., SWEZEY S. E., GIACOMINI J. C., BLASCHKE T. F., 1980. Administration of heparin causes in vitro release of non-esterified fatty acids in human plasma. Life Sci., 27 , 771-780.

HÖCKEL M., DÜNGES W., HOLZER A., BROCKERHOFF P., RATHGEN G. H., 1980. A microliter method for the gas chromatographic determination of long-chain non esterified fatty acids in human serum or plasma. J. Chromat., 221, 205-214.

HOSAKA K., KIKUCHI T., MITSUHIDA N., KAW'AGUCHI A., 1981. A new colorimetric method for the determination of free fatty acids with acyl-Co A synthetase and acyl-Co A oxidase. $J$. Biochem., 89, 1799-1803.

HOWORTH P. J. N., GIBBARD S., MARK V., 1966. Evaluation of a colorimetric method (Duncombe) of determination of plasma non-esterified fatty acids. Clin. chim. Acta, 14, $69-73$.

ITAYA K., UI M., 1965. Colorimetric determination of free fatty acids in biological fluids. J. Lipid Res., 6, 16-20.

KASHKET S., 1971. An automated method for analysis of free fatty acids. Anal. Biochem., 41, 166-172.

KEPLER C. R., HIRONS K. P., Mc NEIL J. J., TOVE S. B., 1966. Intermediates and products of the biohydrogenation of linoleic acid by Butyrivibrio fibrisolvens. J. biol. Chem., 241, 13501354.

LAURELL S., TIBBLING G., 1967. Colorimetric micro-determination of free fatty acids in plasma. Clin. chim. Acta, 16, 57-62.

LORCH E., GEY K. F., 1966. Photometric "titration " of free fatty acids with the Technicon autoanalyzer. Anal. Biochem., 16, 244-252.

Mc DONALD-GIBSON R. G., YOUNG M., 1974. The use of an automatic solid injection system for quantitative determination of plasma long chain non-esterified fatty acids by gas-liquid chromatography. Clin. chim. Acta, 53, 117-126.

MATSUBARA C., NISHIKAWA Y., YOSHIDA Y., TAKAMURA K., 1983. A spectrophotometric method for the determination of free fatty acid in serum using acyl-coenzyme $A$ synthetase and acyl-coenzyme A oxidase. Anal. Biochem., 130, 128-133.

MIZUNO K., TOYOSATO M., YABUMOTO S., TANIMIZU I., HIRAKAWA H., 1980. A neW 
enzymatic method for colorimetric determination of free fatty acids. Anal. Biochem., 108, 6-10.

MOSINGER F., 1965. Photometric adaptation of Dole's micro-determination of free fatty acids. J. Lipid Res., 6. 157-159.

NOVAK M., 1965. Colorimetric ultramicro method for the determination of free fatty acids. J. Lipid Res., 6, 431-433.

OKABE H., UJI Y., NAGASHIMA K., NOMA A., 1980. Enzymatic determination of free fatty acids in serum. Clin. Chem., 26, 1540-1543.

ROGIERS V., 1977. The application of an improved gas-liquid chromatographic method for the determination of the long chain non-esteried fatty acid pattern of blood plasma in children. Clin. chim. Acta, 78, 227-233.

ROGIERS V., 1978. Stabilility of the long chain non-esterified fatty acid pattern in plasma and blood during different storage conditions. Clin. chim. Acta, 84, 49-54.

SHIMIZU S., INOUE K., TANI Y., YAMADA M., 1979. Enzymatic micro-determination of serum free fatty acids. Anal. Biochem., 98, 341-345.

SHIMIZU S., TANI Y., YAMADA H., TABATA M., MURACHI T., 1980. Enzymatic determination of serum-free fatty acids : a colorimetric method. Anal. Biochem., 107, 193-198.

SOLONI F. G., SARDINA L. C., 1973. Colorimetric microdetermination of free fatty acids. Clin. Chem., 19, 419-424.

TROUT D. L., ESTES E. H. Jr., FRIEDBERG S. J., 1960. Titration of free fatty acids of plasma : a study of current methods and a new modification. J. Lipid Res., 1, 199-202. 